\title{
92. Ecdysone in the Eggs of Bombyx Silkworm
}

\author{
By Eiji OHNishi,*) Tetsuya OHTAKI,**) \\ and Soichi FuKUDA*) \\ (Comm. by Yô K. OKAdA, M. J. A., April 12, 1971)
}

Ecdysone is known to regulate molting, growth and differentiation in insects. But the experimental evidence is confined to the so-called 'post-embryonic' development and nothing is known as to the role of this hormone in embryonic development. Wigglesworth stated in his recent monograph that "the growth of insect tissues in the absence of the moulting hormone is likewise evident during embryonic development" (Wigglesworth, 1970). However, there still exists a possibility of the participation of ecdysone even before the development of prothoracic glands, since ecdysone was occasionally demonstrated in adult insects which have no prothoracic gland (Shaaya and Karlson, 1965, Stamm, 1959), and its formation in the isolated abdomen of silkworms has been reported (Moriyama et al., 1970).

The present study approaches this problem by estimating ecdysone titers in the developing eggs and in the diapausing eggs. For this purpose eggs of the commercial silkworm, Bombyx mori, are favorable, since they are easily obtained in quantities and can be conditioned to undergo embryonic diapause before the development of the prothoracic gland.

Materials and methods. Silkworm eggs (10-15 g) of known stages were sampled and ground in a chilled mortar with a mixture of acetone and ethanol ( $1: 1$, by volume). Details of the partial purification and biological assay using isolated abdomens of the fleshfly Sarcophaga were the same as described by Ohtaki and others (Ohtaki et al., 1968).

Results and discussion. Surprisingly, quite high ecdysone titers were detected in the eggs about 24 hours after oviposition. This high level is nearly comparable to that found in the Sarcophaga larvae at the time of puparium formation, when ecdysone reaches its maximal level. Entering diapause, the level dropped to about one-fifth in average, although ecdysone titers fluctuated from sample to sample. After keeping the diapausing eggs at $5{ }^{\circ} \mathrm{C}$ for 52 days, the diapause was broken artificially by treating them with hydro-

*) Biological Institute, Faculty of Science, Nagoya University, Nagoya.

**) Department of Entomology, National Institute of Health, Tokyo. 
Table I. Ecdysone titer (equivalent to ecdysterone) of silkworm eggs before, during and after diapause

\begin{tabular}{lcc}
\hline $\begin{array}{c}\text { Conditions of eggs and } \\
\text { treatment of extract }\end{array}$ & Sample number & $\begin{array}{c}\text { Ecdysone titer } \\
(\mu \mathrm{g} / \mathrm{g})\end{array}$ \\
\hline Before diapause & 1 & \\
$24 \pm 6$ hr after oviposition & 2 & 0.24 \\
& 3 & 0.16 \\
& & 0.19 \\
During diapause & 1 & \\
57 days after oviposition, & 2 & 0.036 \\
kept at room temp. $\left(24-29^{\circ}\right)$ & 3 & 0.042 \\
Stage $\alpha$ & 4 & 0.097 \\
& 5 & 0.060 \\
& 6 & 0.02 \\
Sample of eggs was the same as above, & & 0.02 \\
extract was incubated with $\alpha$-glucosidase & 1 & \\
& 2 & 0.21 \\
Sample of eggs was the same as above, & & 0.087 \\
extract was incubated with buffer only & 1 & 0.14 \\
Post diapause & & \\
24 hr after $\mathrm{HCl}$ treatment, & 1 & 0.14 \\
Stage $\gamma \mathrm{A} \sim \gamma \mathrm{B}$ & 2 & 0.11 \\
72 hr after HCl treatment, & 1 & 0.23 \\
Stage $\varepsilon \mathrm{A} \sim \varepsilon \mathrm{B}$ & 2 & 0.061 \\
\hline
\end{tabular}

chloric acid $\left(20 \% \mathrm{HCl}\right.$ at $48^{\circ}$ for $5.5 \mathrm{~min}$.). They were then incubated at $20^{\circ}$ to allow post-diapause development. After 24 hours, embryos developed to $\gamma \mathrm{A} \sim \gamma \mathrm{B}$ stage, according to the timetable of Mizuno ${ }^{1)}$ (Mizuno, 1936). After further incubation of 48 hours, embryos reached the stage $\varepsilon \mathrm{A} \sim \varepsilon \mathrm{B}$. It should be noted that the prothoracic gland is not yet developed at this stage (Toyama, 1902). Upon resumption of embryonic development, the ecdysone level increased to some extent, but the original level was not recovered.

The low level observed in the diapausing eggs may be due either to breaking down of ecdysone or inactivation by binding with other molecules. Heinrich and Hoffmeister showed that ecdysterone and 25-desoxyecdysterone were rapidly transformed into the corresponding $\alpha$-glucoside in Calliphora larvae (Heinrich and Hoffmeister, 1970). To test the possibility of glucosylation of ecdysone in Bombyx eggs, a part of the acetone-ethanol extract from diapause eggs was incubated with or without $\alpha$-glucosidase (the product of Boehringer

1) In the timetable of Mizuno's monograph, post-diapause stages were classified into 6 stages and each stage was subdivided into 2-3 groups. Since each stage was designated by a Chinese letter, the Chinese letters were transcribed into Greek letters in this paper. 
Mannheim, 9 units per $\mathrm{ml}$ with $0.067 \mathrm{M} \mathrm{K}$ phosphate buffer, $\mathrm{pH}$ 6.8) at $30^{\circ}$ for 2 hours. The ecdysone level was increased to some extent by this treatment, but the same effect was also observed when $\alpha$-glucosidase was omitted from the incubation mixture.

The cause of fluctuation in ecdysone titers is not clear at present. One possibility is that ecdysone is loosely bound to a carrier molecule and is liable to be liberated during the extraction procedure.

The present report is the first demonstration of the presence of ecdysone in the eggs of insects. The high ecdysone titer shortly after oviposition and its reduction during diapause suggest that ecdysone is essential not only for post-embryonic growth but also for embryonic development.

Summary. Ecdysone titer in developing and diapausing eggs of the silkworm, Bombyx mori, was estimated by biological assay using isolated abdomens of Sarcophaga. Quite high ecdysone titer was found in eggs 24 hours after oviposition. The level diminished during the diapause and was re-elevated upon resumption of embryonic development. An essential role for ecdysone in embryonic development is suggested.

Acknowledgment. The authors wish to thank Mr. T. Funada of the Katakura Sericultural Experiment Station, and Mr. T. Inoue of the Katakura Fukyudan for their kindness in providing silkworm eggs. They are also grateful to Dr. C. Donnell Turner for his help in the preparation of the manuscript.

\section{References}

Heinrich, G., and Hoffmeister, H. (1970): Insektenhäutungshormon und ihre Wirkungsweise. Bildung von Hormonglykosiden als Inaktivierungsmechanisms bei Calliphora erythrocephala. Z. Naturforsch., 25b, 358-361.

Mizuno, T. (1936): Sanranron. Meibundo, Tokyo 9th ed. (in Japanese).

Moriyama, H., Nakanishi, K., King, D. S., Okauchi, T., Siddall, J. B., and Hafferl, W. (1970): On the origin and metabolic fate of $\alpha$-ecdysone in insects. Gen. Comp. Endocrinol., 15, 80-87.

Ohtaki, T., Milkman, R. D., and Williams, C. M. (1968): Dynamics of ecdysone secretion and action in the fleshfly Sarcophaga peregrina. Biol. Bull., 135, 322334 .

Shaaya, E., and Karlson, P. (1965): Der Ecdysontiter während der Insektenentwicklung. IV. Die Entwicklung der Lepidopteren Bombyx mori L. und Cerura vinula L. Develop. Biol., 11, 424-432.

Stamm, M. D. (1959): Estudios sobre hormonas de invertebrados. II. Aislamiento de hormonas de la metamorfosis en el ortoptero Dociostaurus maroccanus. Anal. Real. Soc. Espan. Fisica y Quimica (Madrid), 55B, 171-178.

Toyama, K. (1902): Contributions to the study of silk-worms. I. On the embryology of the silk-worms. Bull. Coll. Agr. Tokyo Imp. Univ., 5, 73-117.

Wigglesworth, V. B. (1970): Insect Hormones. Oliver and Boyd, Edinbourgh, p. 17. 